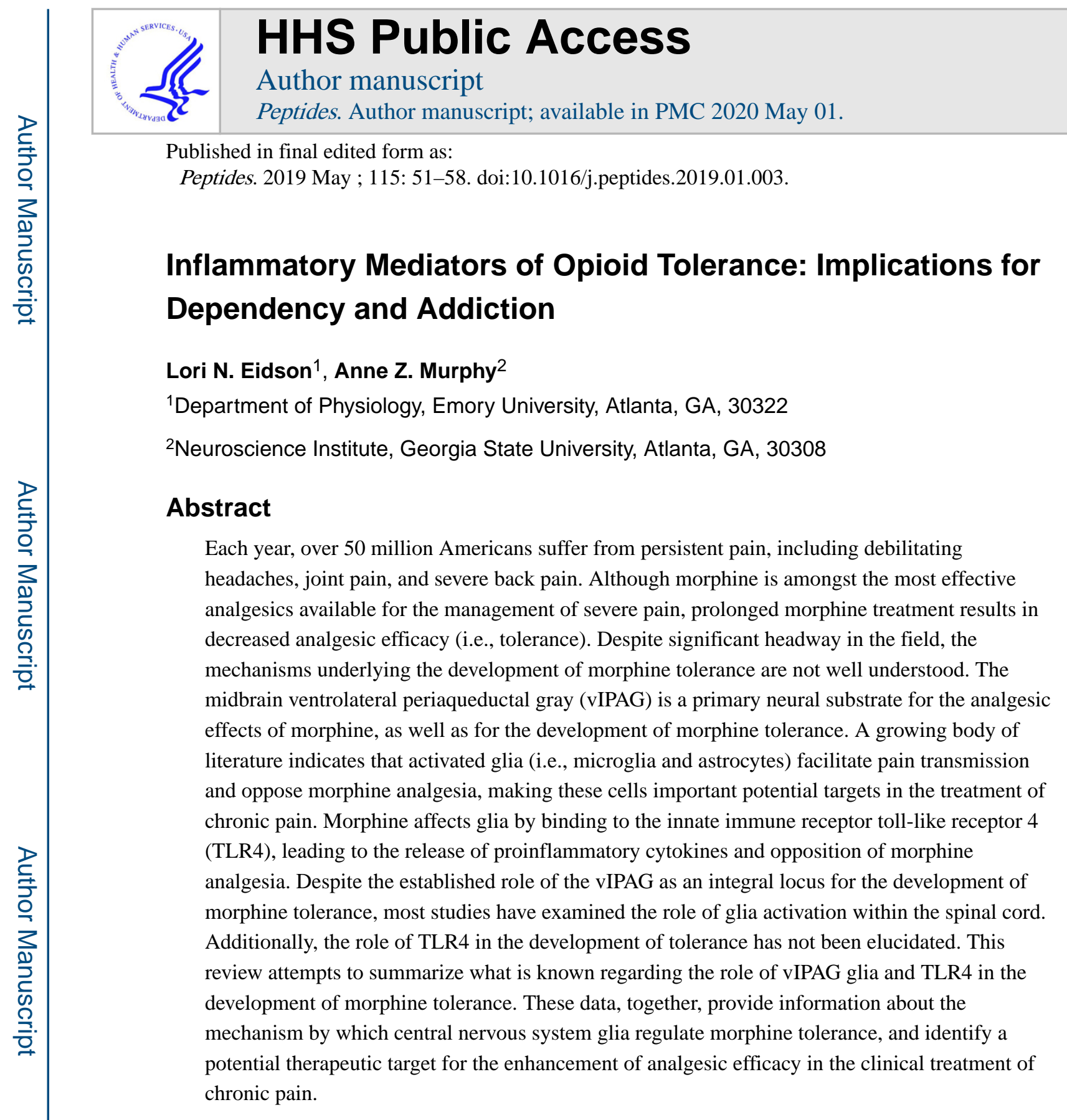

\title{
Keywords
}

Opioid; Tolerance; Glia; Toll-like receptor 4; Tumor necrosis factor; Periaqueductal gray

\footnotetext{
Address for Correspondence: Dr. Anne Z. Murphy, Neuroscience Institute, Georgia State University, PO Box 4010, Atlanta, GA 30302-4010, 404-413-5332, 404-413-5301 (FAX), amurphy@gsu.edu.

Publisher's Disclaimer: This is a PDF file of an unedited manuscript that has been accepted for publication. As a service to our customers we are providing this early version of the manuscript. The manuscript will undergo copyediting, typesetting, and review of the resulting proof before it is published in its final citable form. Please note that during the production process errors may be discovered which could affect the content, and all legal disclaimers that apply to the journal pertain.
} 


\section{Opioids and the Management of Pain}

The perception of pain is an important evolutionary phenomenon that allows escape from danger, avoidance of harmful stimuli, and attention to tissue damage. However, chronic pain perception in the absence of an ongoing injury, or during treatment of an illness, is aversive without purpose and detrimental to quality of life. Chronic pain, defined as pain lasting more than three months, impacts approximately $55 \%$ of the population over the age of 20 , and includes debilitating headaches, joint pain, severe back pain, and cancer-related pain ${ }^{1,2}$. Despite their discovery thousands of years ago, opiates remain the most common and effective option for pain management ${ }^{3}$. Indeed, over $90 \%$ of chronic pain sufferers receive some form of opioid therapy ${ }^{4}$, with morphine being amongst the most commonly prescribed drugs.

In addition to modulating pain, opioids have widespread central and peripheral effects, many of which interfere with the beneficial aspects of opioids ${ }^{5}$. Indeed, the negative side effects associated with opioid consumption, including respiratory depression, gastrointestinal immotility, and addiction render these drugs unsatisfactory for long-term pain management ${ }^{1,6}$. Although a multitude of opioids (man-made drugs sharing similar structures with the plant-derived opium ${ }^{6}$ ) were synthesized in hopes of harnessing the natural analgesic potency of opiates while minimizing the negative side effects, few are as potent as morphine, and the pinnacle, analgesia without the side-effect profile, has not been realized ${ }^{5}$.

The average duration of opioid consumption for chronic pain management is 105 days ${ }^{7}$. Prolonged morphine treatment reduces analgesic efficacy (i.e., tolerance), thereby requiring steadily larger doses for the maintenance of analgesia ${ }^{3}$. Dose escalation increases the risk of developing negative side effects, including anti-analgesia, addiction, withdrawal, and respiratory depression ${ }^{4}$, and is not always sufficient to overcome tolerance and reinstate analgesic efficacy ${ }^{3}$. Indeed, opioid tolerance is a significant impediment for sufficient pain relief in approximately $60 \%$ of patients ${ }^{8}$. However, the mechanisms underlying the development of morphine tolerance are not completely understood, and the role of inflammation has been largely ignored until relatively recently.

\section{Opioid Action in the CNS: The PAG \& the Descending Analgesic Pathway}

The midbrain periaqueductal gray (PAG) and its descending projections to the rostral ventromedial medulla (RVM) and spinal cord comprise a critical neural circuit for both endogenous and exogenous opioid-mediated analgesia ${ }^{9-13}$. The PAG was first identified as an essential neural substrate for pain modulation in the 1960s, when it was demonstrated that electrical stimulation of the rat PAG produces analgesia so profound as to allow for invasive abdominal surgery to be performed in the absence of anesthesia ${ }^{14,15}$. In humans, electrical stimulation of the PAG is still used today for the management of intractable pain ${ }^{16-18}$. PAG stimulation produced analgesia is attenuated by intra-PAG injection of the mu opioid receptor (MOR) antagonist naloxone, ${ }^{19}$ suggesting an opioid-dependent mechanism.

The PAG contains a high density of MOR containing neurons, ${ }^{20-22}$ and microinjection of opioid antagonists into the PAG significantly attenuates the analgesic effects of systemic 
morphine ${ }^{23-25}$. Similarly, site-specific lesions of PAG MOR-containing neurons (using the cytotoxin saporin (a ribosome inactivating protein) conjugated to the MOR ligand Dermorphin) significantly reduce the antinociceptive effects of systemic morphine suggesting that PAG MOR is critical for morphine action ${ }^{26}$. The density of MOR immunoreactivity within the vIPAG is positively correlated with the degree of analgesia produced by morphine, such that male rats with normal levels of MOR immunoreactivity in the vIPAG have significantly lower $\mathrm{ED}_{50}$ values $(4.07 \mathrm{mg} / \mathrm{kg})$ compared with animals in which MOR levels were reduced 2-fold (12.55 mg/kg). Indeed, in animals with low PAG MOR, systemic administration of $10 \mathrm{mg} / \mathrm{kg}$ of morphine results in only a $20 \%$ maximum possible analgesic effect in comparison to $100 \%$ in animals with a complete complement of MOR. Together, these data indicate that the PAG is an essential site for opioid-mediated analgesia.

Morphine and other opioids bind to neuronal $\mathrm{MOR}^{6}$, a prototypical G-protein coupled receptor (GPCR), and are generally thought to elicit analgesia by hyperpolarizing

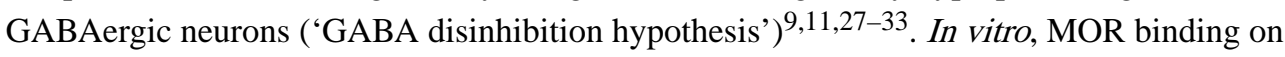
PAG neurons inhibits miniature inhibitory postsynaptic potential frequency and decreases the probability of presynaptic GABA release ${ }^{31,34}$. In vivo, injection of GABA antagonists into the PAG partially mimics the effects of morphine ${ }^{35}$. In part, morphine binding to vIPAG MOR hyperpolarizes GABAergic neurons ${ }^{34,36}$, thereby releasing vIPAG-RVM projection neurons from local tonic inhibition ${ }^{36}$. The PAG signals to RVM neurons, which then signal to the spinal cord to inhibit nociceptive dorsal horn neurons and produce antinociception $^{37-39}$. Indeed, lesions of the RVM and spinal dorsal horn abolish PAG stimulation-produced antinociception, indicating that the PAG-RVM-spinal cord circuit is necessary for both exogenous and endogenous pain modulation ${ }^{40,41}$.

\section{Neuronal Mechanisms of Opioid Tolerance}

In addition to being a critical locus for both endogenous and exogenous pain modulation, the vIPAG is critical for the development of morphine tolerance $24,42-51$. Chronic vIPAG opioid administration results in the rapid development of behaviorally and physiologically defined opioid tolerance. In addition, repeated intra-vIPAG microinjections of morphine ${ }^{49}$ or the potent MOR agonists fentanyl ${ }^{43}$ or DAMGO ${ }^{47,49}$ result in tolerance to systemically administered morphine. Further, chronic administration of morphine into the ventrolateral, but not lateral or dorsal, PAG induces morphine tolerance ${ }^{51}$; this effect remains when the downstream target (RVM) is inhibited with the GABA agonist muscimol. Interestingly, these behavioral and electrophysiological changes underlying tolerance are prevented by intravIPAG injections of the opioid receptor antagonist naltrexone ${ }^{24}$, indicating that the vIPAG is sufficient for the development of morphine tolerance.

Although the mechanisms by which morphine tolerance develops are not entirely understood, many current hypotheses include a role for increased glutamatergic and/or decreased GABAergic signaling ${ }^{31}$. Cerebrospinal fluid (CSF) from morphine-tolerant humans contains significantly higher levels of both glutamate and aspartate ${ }^{52}$, and morphine challenge increases glutamate in the CSF of morphine tolerant rats ${ }^{53}$. Increased expression of AMPA and NMDA receptor subunits ${ }^{54}$ and increased NMDA receptor binding ${ }^{55}$ in the rat 
spinal cord has been shown to accompany tolerance development. Along these same lines, blockade of spinal cord glutamatergic signaling by intrathecal administration of NMDA ${ }^{56-61}$ and AMPA ${ }^{62,63}$ receptor antagonists attenuates morphine tolerance. Together, these data indicate that, at least at the level of the spinal cord, opioid tolerance is accompanied by an increase in the excitatory neuroenvironment that is mediated by changes in glutamatergic signaling.

Studies examining the cellular responses of PAG neurons indicate that morphine tolerance, induced by repeated systemic or intra-vIPAG morphine, decreases the ability of opioids to initiate signaling through the PAG-RVM descending analgesic circuit ${ }^{44,45}$. Repeated pharmacological activation of the PAG-RVM circuit via direct microinjection of the excitatory amino acid agonist kainate or the GABAergic antagonist bicuculine is not sufficient to induce tolerance, indicating that tolerance requires opiate activation of MORexpressing GABAergic neurons that synapse onto PAG-RVM output neurons ${ }^{48}$. Indeed, Morgan and colleagues recently demonstrated that chronic vIPAG microinjections of morphine results in tolerance that is dependent on alterations in pre- and post-synaptic GABA release ${ }^{42}$. Chronic systemic morphine results in tolerance as evidenced by a decreased ability of MOR agonists to inhibit $\mathrm{Ca}^{2+}$ and activate $\mathrm{K}^{+}$channels in dissociated neuronal cultures from the PAG or PAG slices ${ }^{64}$. Although NMDA receptor signaling is not important for PAG-mediated opioid tolerance ${ }^{65,66}$, data from the PAG supports a role for increased neuroexcitability in tolerance development. For example, intra-PAG microinjections of the cholecystokinin (CCK) antagonist proglumide prevent and even reverse tolerance to repeated PAG microinjections of morphine ${ }^{67}$. CCK excites neurons by opening depolarizing currents and inhibiting $\mathrm{K}+$ conductance $^{68-70}$, thereby directly opposing the mechanisms by which morphine hyperpolarizes neurons. Together, these data suggest that increased neuroexcitability at the level of the PAG significantly contributes to opioid analgesic tolerance by decreasing the ability of opioids to hyperpolarize neurons.

\section{Glial Mechanisms of Opioid Tolerance}

Since the 1990's basic research has shifted focus from exclusive investigation of neuronal mechanisms underlying opiate analgesia and tolerance to investigation of both neuronal and central nervous system (CNS) glial involvement. It is now well established that chronic morphine induces a robust neuroinflammatory response in the CNS that enhances neuronal excitability and contributes to tolerance ${ }^{71-87}$. Although the importance of the VIPAG in tolerance development is well established, the majority of investigation of glial involvement in opioid signaling has been limited to spinal and medullary loci $81,85,88-90$.

Several lines of evidence implicate opioids as activators of CNS astrocytes and microglia ${ }^{85}$. In the spinal cord, morphine increases protein levels of the microglia and astrocyte activity markers OX-42 and glial fibrillary acidic protein (GFAP), respectively, ${ }^{71,72,91}$ and induces release of glially-derived proinflammatory cytokines ${ }^{73,74,81,84,86,87,90}$. Proinflammatory cytokines have been shown to decrease GABA receptor expression, increase the number and the conductance of AMPA and NMDA receptors, decrease glutamate transporter proteins, and decrease outward potassium currents ${ }^{85}$, resulting in an overall increase in neuroexcitability. Functionally, administration of the glial metabolic inhibitors 
propentofylline, fluorocitrate, and minocycline reduce spinal OX-42, GFAP, and cytokines, and attenuate morphine tolerance ${ }^{72,76,87,91-97}$. Importantly, glial release of cytokines increases exponentially with repeated morphine administration, ${ }^{84}$ making these excitatory substances key players in the development of morphine tolerance.

Both morphine tolerance and opioid-induced sensitivity to pain (hyperalgesia) following repeated exposure to morphine is still observed in neuronal opioid receptor (mu, delta and kappa) knock out mice ${ }^{98}$, suggesting that the anti-analgesic effects of morphine are not mediated by traditional opioid receptor signaling. Recent in vivo and in vitro data confirm this, and demonstrate that the proinflammatory effects of morphine are mediated through the innate immune receptor Toll-like receptor 4 (TLR4) ${ }^{81}$. TLR4 is found on microglia, and to a lesser degree, astrocytes ${ }^{99,100}$. Opioids, including morphine, bind to the glycoprotein myeloid differentiation factor-2 (MD-2) on TLR $4^{78,79}$, and initiate an inflammatory response through nuclear factor kappa $\mathrm{B}(\mathrm{NF \kappa B})$ activation and $\mathrm{p} 38$ mitogen activated protein kinase (MAPK) phosphorylation ${ }^{81}$. Activation of the NFKB pathway results in the robust release of proinflammatory cytokines including tumor necrosis factor, (TNF), Interleukin $1 \beta$ eta (IL-1 $\beta$ ), and Interleukin 6 (IL-6) ${ }^{78,79,81}$. Spinal TLR4 activity opposes the acute effects of morphine, including antinociception, and contributes to opioid-induced hyperalgesia ${ }^{78,79}$, and systemic TLR4 antagonists prevent tolerance to systemic morphine ${ }^{78}$.

A nearly ubiquitous characteristic of opioid-induced neuroinflammation is TNF production, likely mediated via TLR4. Chronic systemic ${ }^{101}$ or intrathecal morphine administration increases TNF mRNA ${ }^{84,86,102,103}$ and protein $53,86,101,102,104,105$ in the rodent spinal cord, and TNF levels increase with the chronicity of morphine treatment ${ }^{84}$. Inhibition of spinal TNF signaling decreases morphine-induced release of proinflammatory cytokines (e.g., TNF, IL-1 $\beta$, and IL-6) and activation of p38 MAPK ${ }^{54,102,106}$, indicating that TNF induces a positive feedback loop of neuroinflammation that contributes to decreased morphine efficacy. Functionally, immunomodulatory drugs that attenuate, abolish, or even reverse morphine tolerance (e.g., ibudilast (AV411) ${ }^{97,107}$, minocycline ${ }^{76,91,96,97,108}$, fluorocitrate ${ }^{72,82}$, propentofylline ${ }^{82,87,93,94,109}$ ) decrease the expression of TNF. However, these immunomodulatory drugs have widespread and non-specific effects, altering expression levels of several cytokines implicated in opioid tolerance, including IL-1 $\beta^{86,101,110}$ and IL-6 $6^{86,87,101}$. Although these data indicate that spinal TNF plays a significant role in morphine-induced inflammation and the development of morphine tolerance $^{72-74,76,84-87,93,111,112}$, remarkably, very few studies have directly tested the role of TNF in isolation ${ }^{54,102,106 .}$

\section{Inflammation significantly contributes to morphine tolerance}

Many mechanisms have been proposed to account for opioid tolerance, including MOR decoupling, internalization, and/or down-regulation of MORs ${ }^{113,114}$. However, in comparison to other opioids (e.g., DAMGO, fentany $1^{6}$ ), morphine does not result in MOR internalization, and is remarkably weak in terms of decreasing G-protein signaling and receptor desensitization ${ }^{115,116}$. Indeed, chronic morphine increases G-protein efficiency in the vIPAG ${ }^{42}$. Together with our recently published work (reviewed below) ${ }^{82,83,117}$, these 
data suggest mechanisms other than MOR signaling also contribute to morphine tolerance at the level of the midbrain PAG.

Under basal conditions, microglia and astrocytes survey the environment for pathogens, including viruses and bacteria. Disturbances in homeostasis results in the rapid activation of glia, evidenced by a profound shift in morphology that can be easily visualized using immunohistochemistry for OX-42 and Ibal (microglia) and glial fibrillary acidic protein (GFAP; astrocytes) ${ }^{118}$. Glial activation also results in the increased production and release of pro-inflammatory cytokines (including IL-1 $\beta$, IL-6, and TNF), chemokines, ATP, excitatory amino acids, and NO, all of which increase the excitability of nearby neurons ${ }^{86,93}$. Indeed, glially-derived cytokine release results in increases in the number and conductance of AMPA $^{119,120}$ and NMDA ${ }^{121}$ receptors, decreases in astrocytic glutamate transporter proteins ${ }^{85}$, and down-regulation of GABA receptors ${ }^{120}$. Microglia derived IL- $1 \beta$ and TNF bind to receptors on astrocytes, resulting in the further release of IL-1 $\beta$, IL-6, and TNF ${ }^{86}$. These cytokines actively oppose the analgesic actions of morphine ${ }^{71}$.

Acute and chronic morphine administration activates microglia and astrocytes $^{28,48,49,72,86,91-93,122}$, with the degree of glial activation increasing with duration of opioid treatment ${ }^{81}$. Increased opioid consumption and the ensuing glial activation ultimately results in the opposition of morphine analgesia and the development of morphine tolerance. Studies by Song and Zhou (2001), as well as others, have shown that inhibition of spinal glia activation with general glial metabolic inhibitors results in a partial attenuation in morphine tolerance ${ }^{71,73,84,86,87}$. Interestingly, spinal glia activation induced by other stimuli, such as neuropathic pain or lipopolysaccharide (LPS; a potent TLR4 agonist) administration, also reduces the analgesic efficacy of morphine ${ }^{88}$.

Complementing literature from the spinal cord and RVM, we have demonstrated that glial activation within the PAG is critical for the development of morphine tolerance. First, we found that administration of a single $\mathrm{ED}_{50}$ dose of morphine once a day for 3 days (but not administration of a single $\mathrm{ED}_{50}$ dose of morphine once a day for only 1 day) significantly activated both microglia and astrocytes in the PAG, as indicated by a 2-fold increase in 0X42 and GFAP protein levels (when measured 24 hours later) ${ }^{83}$. 0X42 and GFAP expression within the PAG paralleled the development of morphine tolerance such that animals that were tolerant to the antinociceptive effects of morphine had the highest 0X42 and GFAP immunoreactivity ${ }^{82,83}$. Persistent peripheral hyperalgesia induced by intraplantar administration of complete Freund's adjuvant (CFA), significantly attenuated the development of morphine tolerance, and no significant differences were noted in vIPAG glial cell activation for CFA + Saline and CFA + Morphine treated animals versus controls $(\text { Handled }+ \text { Saline })^{83}$. These data mirror clinical data indicating that peripheral pain delays the development of tolerance ${ }^{123-126}$, and suggest that there is something unique about persistent pain that blocks morphine from activating glia. Morgan and colleagues reported that intraplantar CFA prevents tolerance to chronic intra-vIPAG microinjections of morphine ${ }^{127}$, and Tonsfeldt et al. recently demonstrated that morphine elicits increased antinociception in female rats following CFA treatment, and that this is dependent on modulation of PAG GABA receptor activity $^{128}$. These data corroborate our results, and suggest that pain-induced changes in the vIPAG are responsible for the preservation of 
opioid analgesia during a persistent pain state. These results suggest that peripheral pain site-specifically prevents glial cell activation in the PAG, and are in contrast to several studies at the level of the spinal cord and medulla (i.e., RVM) demonstrating that peripheral pain, including CFA ${ }^{129-133}$, peripheral neuropathy ${ }^{71,90,94,118,132,134,135}$, formalin ${ }^{136}$, and spinal nerve ligation ${ }^{137}$ induce significant glia activation. However, given the unique roles of the PAG and spinal cord in pain modulation and pain facilitation, respectively, it is not entirely surprising that there would be differential pain-induced regulation of glial activation in these two sites.

\section{VIPAG TLR4 and morphine tolerance}

It is well established that morphine activates glia and that glia contribute to morphine tolerance. However, it was not until 2010 that the mechanism by which morphine activates glia was discovered. At that time, the innate immune receptor, TLR4, was shown to bind opioids like morphine and mediate glial cell activation ${ }^{78}$. TLR4 is found primarily on microglia, and to a lesser degree on astrocytes, but not neurons ${ }^{99,100}$. TLR4 recognizes the endotoxin lipopolysaccharide (LPS; the prototypical TLR4 agonist), endogenous danger signals including "alarmins" (e.g., fragments of self DNA in the extracellular space that indicate cell nucleus damage), and certain xenobiotics including both synthetic (e.g., morphine, naloxone, oxycodone, buprenorphine, fentany ${ }^{78}$ ) and endogenous (e.g., $\mathrm{M}^{3} \mathrm{G}^{79}$ ) opioids. Interestingly, MOR binds M6G, but not M3G ${ }^{6}$. Conversely, TLR4 binds M3G but not M6G ${ }^{79,89,148}$. Unlike MOR, which only binds the (-)-stereoisomer of opioids, TLR4 binds opioid agonists and antagonists in a non-stereoselective fashion that maintains their agonistic and antagonistic properties at TLR4 ${ }^{78}$. TLR4 agonists, including opioids and LPS, bind to the MD2 region of TLR4 resulting in activation of three separate signaling cascades: the PI3K/Akt, NFkB, and the MAPK pathway ${ }^{81}$. The former results in cell motility and apoptosis and the latter two pathways are responsible for the production of proinflammatory substances such as cytokines.

It is now clear that TLR4 signaling contributes to the development of morphine tolerance ${ }^{78,117}$. Recent in vivo and in vitro data demonstrate that the innate immune receptor TLR4, but not $\mathrm{MOR}^{81}$, mediates morphine-induced cytokine release (including TNF) ${ }^{78,79,81}$. Chronic morphine increases TLR4 mRNA expression ${ }^{79,117,149}$ and downstream products of the TLR4 signaling cascade (e.g., IL-1 $\beta$ ); similarly, systemic TLR4 antagonists attenuate tolerance to systemic morphine ${ }^{78,82}$. These data further elucidate the mechanisms by which morphine alters glia activity, and suggest that vIPAG glia contribute to the development of morphine tolerance via TLR4 signaling.

We recently demonstrated, for the first time, the expression of the TLR4 co-receptor myeloid differentiation factor 2 (MD2) in the PAG, indicating the presence of TLR4 ${ }^{82}$. MD-2 immunoreactivity was significantly denser in PAG regions important for morphine analgesia (lateral and ventrolateral PAG) as compared with other subnuclei (dorsal PAG), indicating a mechanism whereby morphine may preferentially activate glia in the vIPAG. Indeed morphine-induced OX-42, Ibal, and GFAP expression is most robust in ventral PAG regions ${ }^{83}$. Our recent data also indicate that vIPAG microinfusions of TLR4 antagonists, including (+)-naloxone, dose-dependently prevented tolerance to systemic morphine. In 
parallel, we showed that VIPAG microinfusions of TLR4 agonists (in the absence of morphine) dose-dependently produced a naive tolerance to subsequent challenge doses of morphine (indicated by a significant 3-fold rightward shift in the morphine dose-response curve $)^{82,117}$. Together these data are the first to identify a CNS locus through which TLR4 signaling modulates opioid tolerance. It is important to note that studies demonstrating the necessity of MOR signaling in tolerance development using 'opioid-specific' ligands may need to be re-evaluated, as TLR4 binds several of these ligands, including naloxone, in a manner that maintains their agonistic and antagonistic properties ${ }^{78}$.

\section{vIPAG TLR4 modulates morphine tolerance via soluble TNF signaling}

Although TNF contributes to morphine-induced inflammation and the development of morphine tolerance at the level of the spinal cord $72-74,76,84-87,93,111,112$, remarkably, few studies have investigated the role of TNF signaling within the vIPAG, and very few studies have directly tested the role of TNF in isolation ${ }^{54,102,106}$. Additionally, the specific roles of the two natural forms of TNF (tmTNF and solTNF) have not been dissected. Glia activation by opioids induces the production of the cytokines IL-1 $\beta$, IL-6, and TNF, as well as neuroexcitotoxic free radicals (NO, NOS, iNOS); these signaling factors have all been implicated in opioid tolerance ${ }^{71}$. IL- $1 \beta$ and TNF bind to their target receptors on astrocytes and microglia resulting in the further release of proinflammatory factors (e.g., IL-1 $\beta$, IL-6, TNF, ATP, nitric oxide synthase; NOS, and brain derived neurotrophic factor; BDNF); this effectively induces a positive feedback loop of neuroinflammation ${ }^{71,85,88,89}$. BDNF binds to its neuronal receptor TrkB, which further contributes to neuronal excitability by initiating a depolarizing shift in anion reversal potential and increasing intracellular $\mathrm{Cl}^{-}$such that GABA binding becomes depolarizing ${ }^{150}$. BDNF also increases AMPA subunits and the NMDAR subunit NR2A $\mathrm{A}^{151,152}$. These subunits have been referred to as 'anti-opioid subunit' due to the fact that NR2A knock-out mice do not develop morphine tolerance ${ }^{153}$. Together, these data indicate that morphine induced glial activation results in the release of an overwhelming number of factors that result in a 'hyper-excitatory' environment that contributes to morphine tolerance.

Corroborating a vast body of work in the spinal cord, we recently demonstrated that chronic morphine-induced tolerance significantly increased vIPAG TLR4 mRNA ${ }^{117}$ and increased proinflammatory cytokine expression (IL-1 $\beta$, TNF, and IL-6) in the vIPAG. These results confirm previous studies suggesting that chronic morphine induces an increase in the immune receptor substrate to which it binds, thereby priming glia to over-respond to subsequent opioid exposures ${ }^{149}$. We also demonstrated that morphine tolerance was accompanied by a significant decrease in astrocytic glutamate transporter mRNA (GLT-1 and GLAST) in the vIPAG ${ }^{117}$. Neuronal glutamate transporter mRNA (EAAC1) was not affected by chronic morphine administration, suggesting that opioids preferentially alter vIPAG astrocytic glutamate uptake to oppose the hyperpolarizing effects of morphine, and lead to tolerance. Chronic intra-vIPAG microinjections of the TLR4 agonist LPS (in the absence of morphine) mimicked the effects of morphine on GLT-1 and GLAST in the $\mathrm{vIPAG}^{117}$, suggesting that TLR4 mediates the inflammatory effects of chronic morphine. These results are consistent with previous studies demonstrating that cytokines increase neuronal excitability. Indeed, in vitro and in vivo ${ }^{54,119-121}$ studies have reported that 
cytokines increase the number and conductance of AMPA and NMDA receptors, decrease astrocytic glutamate transporter proteins (GLT-1 and GLAST) $53,54,159$, decrease GABA receptors and GABA currents ${ }^{120}$, and increase presynaptic release of neurotransmitters ${ }^{71}$.

TNF is a major inflammatory signal released upon TLR4 activation. The inhibitor protein, dominant-negative TNF (DN-TNF), is a well-characterized variant of native human TNF that has been engineered to effectively sequester native solTNF and preclude it from initiating signaling through TNFRI by preventing receptor binding ${ }^{160}$. The use of DN-TNF to manipulate solTNF signaling is highly advantageous in that it spares the beneficial effects mediated by the transmembrane TNF (tmTNF) signal ${ }^{160,161}$. Using a lentiviral vector encoding dominant negative TNF (DN-TNF) or a brain-permeable DN-TNF peptide (XPro ${ }^{\circledR} 1595$ ), we have demonstrate that vIPAG sequestration of soluble TNF (solTNF) abolishes tolerance to systemic morphine as well as naive tolerance to morphine induced by intra-vIPAG injections of the TLR4 agonist LPS ${ }^{117}$. vIPAG injections of lenti-DN-TNF also prevented the morphine-induced decreases in GLT-1 and GLAST, and systemically injected $\mathrm{XPro}^{\circledR} 1595$ prevented the morphine-induced increase in IL- $1 \beta$ and TLR4 mRNA in the vIPAG, and eliminated the trending increase in TNF and IL-6 mRNA. These results complement work from Shen and colleagues demonstrating that chronic intrathecal morphine induces tolerance that is accompanied by decreases in spinal GLT-1 and GLAST, and increases in AMPA and NMDA receptor subunits. These authors further showed that one intrathecal injection of the general TNF decoy receptor Etanercept (that blocks solTNF and tmTNF signaling) was sufficient to rescue morphine analgesia in morphine tolerant mice, and prevent morphine-induced alterations in glutamatergic signaling ${ }^{54,102}$. Our results are consistent with this work, and indicate for the first time that solTNF (TNFRI), and not tmTNF (TNFRI and TNFRII) signaling, is important for morphine tolerance.

Our data are also novel in that we identify a neural locus through which TLR4 contributes to morphine tolerance, and indicate that TLR4-induced soluble TNF signaling (through TNFRI) is responsible for the anti-analgesic effects of morphine-TLR4 binding. Together, these data support our working hypothesis and indicate that morphine binds to TLR4 within the vIPAG, leading to the release of solTNF. Our results further suggest that solTNF mediates morphine tolerance in the PAG via TNFRI signaling and augmentation of glutamate homeostasis. Given that PAG-mediated analgesia depends largely on the ability of opioids to inhibit vIPAG MOR-expressing GABAergic neurons $12,19,22,39,43,47,65,162-186$, our data suggest that TLR4 signaling contributes to opioid tolerance by decreasing the ability of morphine to hyperpolarize vIPAG GABAergic neurons, thereby maintaining tonic inhibition of vIPAG-RVM projections neurons, and preventing opioid analgesia.

\section{Summary}

Glia modulation of opioid tolerance has been reported at every major level of the descending analgesic circuit: PAG, RVM, and spinal cord dorsal horn. Our recent results are the first to identify (1) a role for PAG glia in the development of morphine tolerance; (2) a neural locus through which TLR4 modulates morphine tolerance development; (3) solTNF as the important TNF form mediating opioid tolerance and alterations in glutamate homeostasis; and (4) release of PAG cytokines in the development of morphine tolerance (see Figure 1). 
Additionally, our studies identify the anti-TNF biologic XPro ${ }^{\circledR} 1595$ as a potential tool to accompany opioid therapy in the clinic. XPro ${ }^{\circledR} 1595$ may be preferable over current FDA approved anti-TNF biologics (Etanercept, Infliximab, Adalimumab) as these drugs block both forms of TNF and are associated with encephalic lesions, neuritis, multiple sclerosis, and other demyelinating diseases ${ }^{187}$. Our studies have further demonstrated that exclusive sequestration of solTNF prevents opioid induced neuroinflammation and the ensuing changes in glutamate homeostasis and development of morphine tolerance. Importantly, these data indicate that tmTNF signaling (TNFRI and TNFRII) is not sufficient for opioid tolerance development. As TNFRII is protective against glutamate excitotoxicity ${ }^{188}$, these data indicate that TNFRII signaling may be a critical countermeasure to opioid-induced neuroexcitability.

\section{Acknowledgements:}

This work was supported by NIH R01DA041529 (AZM). LNE was supported by a generous fellowship from the Honeycutt Foundation.

\section{References}

\section{Literature Cited}

1. Rauck RL What is the case for prescribing long-acting opioids over short-acting opioids for patients with chronic pain? A critical review. Pain Pract 9, 468-479, doi:10.1111/j.1533-2500.2009.00320.x (2009). [PubMed: 19874536]

2. Siddall PJ \& Cousins MJ Persistent pain as a disease entity: implications for clinical management. Anesth Analg 99, 510-520, table of contents, doi:10.1213/01.ANE.0000133383.17666.3A (2004). [PubMed: 15271732]

3. Trescot AM et al. Effectiveness of opioids in the treatment of chronic non-cancer pain. Pain Physician 11, S181-200 (2008). [PubMed: 18443639]

4. Trescot AM et al. Opioid guidelines in the management of chronic non-cancer pain. Pain Physician 9, 1-39 (2006). [PubMed: 16700278]

5. Williams JT et al. Regulation of mu-opioid receptors: desensitization, phosphorylation, internalization, and tolerance. Pharmacol Rev 65, 223-254, doi:10.1124/pr.112.005942 (2013). [PubMed: 23321159]

6. Pasternak GW \& Pan YX Mu opioids and their receptors: evolution of a concept. Pharmacol Rev 65, 1257-1317, doi:10.1124/pr.112.007138 (2013). [PubMed: 24076545]

7. Roggeri $\mathrm{D}$ et al. Resource consumption and costs of treating pain in patients affected by cancer in a district of northeast Italy. Pharmacol Res 56, 329-334, doi:10.1016/j.phrs.2007.08.001 (2007). [PubMed: 17851088]

8. Gulur P, Williams L, Chaudhary S, Koury K \& Jaff M Opioid tolerance--a predictor of increased length of stay and higher readmission rates. Pain Physician 17, E503-507 (2014). [PubMed: 25054400]

9. Basbaum AI \& Fields HL Endogenous pain control mechanisms: review and hypothesis. Ann Neurol 4, 451-462, doi:10.1002/ana.410040511 (1978). [PubMed: 216303]

10. Fields HL \& Basbaum AI Brainstem control of spinal pain-transmission neurons. Annu Rev Physiol 40, 217-248, doi:10.1146/annurev.ph.40.030178.001245 (1978). [PubMed: 205165]

11. Basbaum AI \& Fields HL Endogenous pain control systems: brainstem spinal pathways and endorphin circuitry. Annu Rev Neurosci 7, 309-338, doi:10.1146/annurev.ne.07.030184.001521 (1984). [PubMed: 6143527]

12. Behbehani MM \& Fields HL Evidence that an excitatory connection between the periaqueductal gray and nucleus raphe magnus mediates stimulation produced analgesia. Brain Res 170, 85-93 (1979). [PubMed: 223721] 
13. Beitz AJ The midbrain periaqueductal gray in the rat. I. Nuclear volume, cell number, density, orientation, and regional subdivisions. J Comp Neurol 237, 445-459, doi:10.1002/cne.902370403 (1985). [PubMed: 4044895]

14. Mayer DJ, Wolfle TL, Akil H, Carder B \& Liebeskind JC Analgesia from electrical stimulation in the brainstem of the rat. Science 174, 1351-1354 (1971). [PubMed: 5167502]

15. Reynolds DV Surgery in the rat during electrical analgesia induced by focal brain stimulation. Science 164, 444-445 (1969). [PubMed: 4887743]

16. Green AL et al. Intra-operative deep brain stimulation of the periaqueductal grey matter modulates blood pressure and heart rate variability in humans. Neuromodulation 13, 174-181, doi:10.1111/j. 1525-1403.2010.00274.x (2010). [PubMed: 21992829]

17. Owen SL et al. Deep brain stimulation for neuropathic pain. Acta Neurochir Suppl 97, 111-116 (2007).

18. Levy R, Deer TR \& Henderson J Intracranial neurostimulation for pain control: a review. Pain Physician 13, 157-165 (2010). [PubMed: 20309382]

19. Akil H, Mayer DJ \& Liebeskind JC Antagonism of stimulation-produced analgesia by naloxone, a narcotic antagonist. Science 191, 961-962 (1976). [PubMed: 1251210]

20. Commons KG, Aicher SA, Kow LM \& Pfaff DW Presynaptic and postsynaptic relations of muopioid receptors to gamma-aminobutyric acid-immunoreactive and medullary-projecting periaqueductal gray neurons. J Comp Neurol 419, 532-542, doi:10.1002/ (SICI)1096-9861(20000417)419:4-532::AID-CNE8>3.0.CO;2-6 [pii] (2000). [PubMed: 10742719]

21. Commons KG, van Bockstaele EJ \& Pfaff DW Frequent colocalization of mu opioid and NMDAtype glutamate receptors at postsynaptic sites in periaqueductal gray neurons. J Comp Neurol 408, 549-559. (1999). [PubMed: 10340504]

22. Wang $\mathrm{H} \&$ Wessendorf MW Mu- and delta-opioid receptor mRNAs are expressed in periaqueductal gray neurons projecting to the rostral ventromedial medulla. Neuroscience 109, 619-634 (2002). [PubMed: 11823071]

23. Bernal SA, Morgan MM \& Craft RM PAG mu opioid receptor activation underlies sex differences in morphine antinociception. Behav Brain Res 177, 126-133, doi:S0166-4328(06)00588-2 [pii] 10.1016/j.bbr.2006.10.028(2007) [PubMed: 17118467]

24. Lane DA, Patel PA \& Morgan MM Evidence for an intrinsic mechanism of antinociceptive tolerance within the ventrolateral periaqueductal gray of rats. Neuroscience 135, 227-234, doi: 10.1016/j.neuroscience.2005.06.014 (2005). [PubMed: 16084660]

25. Zambotti $\mathrm{F}$ et al. Periaqueductal gray matter involvement in the muscimol-induced decrease of morphine antinociception. Naunyn Schmiedebergs Arch Pharmacol 318, 368-369 (1982). [PubMed: 7078669]

26. Loyd DR, Wang X \& Murphy AZ Sex differences in micro-opioid receptor expression in the rat midbrain periaqueductal gray are essential for eliciting sex differences in morphine analgesia. J Neurosci 28, 14007-14017, doi:28/52/14007 [pii]10.1523/JNEUROSCI.4123-08.2008 (2008) [PubMed: 19109484]

27. Famaey JP, Fontaine J \& Reuse J Inhibiting effects of morphine, chloroquine, nonsteroidal and steroidal anti-inflammatory drugs on electrically-induced contractions of guinea-pig ileum and the reversing effect of prostaglandins. Agents Actions 5, 354-358 (1975). [PubMed: 1211309]

28. Capogna M, Gahwiler BH \& Thompson SM Mechanism of mu-opioid receptormediated presynaptic inhibition in the rat hippocampus in vitro. J Physiol 470, 539-558 (1993). [PubMed: 8308742]

29. Thompson SM, Capogna M \& Scanziani M Presynaptic inhibition in the hippocampus. Trends Neurosci 16, 222-227 (1993). [PubMed: 7688163]

30. Lau BK \& Vaughan CW Descending modulation of pain: the GABA disinhibition hypothesis of analgesia. Curr Opin Neurobiol 29C, 159-164, doi:10.1016/j.conb.2014.07.010 (2014).

31. Vaughan CW, Ingram SL, Connor MA \& Christie MJ How opioids inhibit GABA-mediated neurotransmission. Nature 390, 611-614, doi:10.1038/37610 (1997). [PubMed: 9403690] 
32. Finnegan TF, Chen SR \& Pan HL Effect of the $\{\mathrm{mu}\}$ opioid on excitatory and inhibitory synaptic inputs to periaqueductal gray-projecting neurons in the amygdala. J Pharmacol Exp Ther 312, 441-448, doi:10.1124/jpet.104.074633 (2005). [PubMed: 15388784]

33. Finnegan TF, Li DP, Chen SR \& Pan HL Activation of mu-opioid receptors inhibits synaptic inputs to spinally projecting rostral ventromedial medulla neurons. J Pharmacol Exp Ther 309, 476-483, doi:10.1124/jpet.103.064808 (2004). [PubMed: 14724227]

34. Vaughan CW et al. Cellular actions of opioids on periaqueductal grey neurons from C57B16/J mice and mutant mice lacking MOR-1. Br J Pharmacol 139, 362-367, doi:10.1038/sj.bjp.0705261 (2003). [PubMed: 12770941]

35. Moreau JL \& Fields HL Evidence for GABA involvement in midbrain control of medullary neurons that modulate nociceptive transmission. Brain Res 397, 37-46 (1986). [PubMed: 3801864]

36. Park $\mathrm{C}$ et al. T-type channels control the opioidergic descending analgesia at the low thresholdspiking GABAergic neurons in the periaqueductal gray. Proc Natl Acad Sci U S A 107, 1485714862, doi:10.1073/pnas.1009532107 (2010). [PubMed: 20682748]

37. Liebeskind JC, Guilbaud G, Besson JM \& Oliveras JL Analgesia from electrical stimulation of the periaqueductal gray matter in the cat: behavioral observations and inhibitory effects on spinal cord interneurons. Brain Res 50, 441-446 (1973). [PubMed: 4705513]

38. Fields HL, Basbaum AI, Clanton CH \& Anderson SD Nucleus raphe magnus inhibition of spinal cord dorsal horn neurons. Brain Res 126, 441-453 (1977). [PubMed: 861731]

39. Carstens E, Stelzer B \& Zimmermann M Microinjections of glutamate or morphine at coincident midbrain sites have different effects on nociceptive dorsal horn neurons in the rat. Neurosci Lett 95, 185-191 (1988). [PubMed: 2906415]

40. Proudfit HK \& Anderson EG Morphine analgesia: blockade by raphe magnus lesions. Brain Res 98, 612-618 (1975). [PubMed: 1182544]

41. Basbaum AI, Marley NJ, O'Keefe J \& Clanton CH Reversal of morphine and stimulus-produced analgesia by subtotal spinal cord lesions. Pain 3, 43-56 (1977). [PubMed: 876666]

42. Bobeck EN, Chen Q, Morgan MM \& Ingram SL Contribution of Adenylyl Cyclase modulation of pre- and postsynaptic GABA neurotransmission to morphine antinociception and tolerance. Neuropsychopharmacology 39, 2142-2152, doi:10.1038/npp.2014.62 (2014). [PubMed: 24622471]

43. Bobeck EN, Haseman RA, Hong D, Ingram SL \& Morgan MM Differential development of antinociceptive tolerance to morphine and fentanyl is not linked to efficacy in the ventrolateral periaqueductal gray of the rat. J Pain 13, 799-807, doi:10.1016/j.jpain.2012.05.005 (2012). [PubMed: 22766006]

44. Lane DA, Tortorici V \& Morgan MM Behavioral and electrophysiological evidence for tolerance to continuous morphine administration into the ventrolateral periaqueductal gray. Neuroscience 125, 63-69, doi:10.1016/j.neuroscience.2004.01.023 (2004). [PubMed: 15051146]

45. Loyd DR, Morgan MM \& Murphy AZ Sexually dimorphic activation of the periaqueductal grayrostral ventromedial medullary circuit during the development of tolerance to morphine in the rat. Eur J Neurosci 27, 1517-1524, doi:10.1111/j.1460-9568.2008.06100.x (2008). [PubMed: 18364026]

46. Macey TA et al. Extracellular signal-regulated kinase $1 / 2$ activation counteracts morphine tolerance in the periaqueductal gray of the rat. J Pharmacol Exp Ther 331, 412-418, doi:10.1124/jpet. 109.152157 (2009). [PubMed: 19684256]

47. Meyer PJ, Fossum EN, Ingram SL \& Morgan MM Analgesic tolerance to microinjection of the micro-opioid agonist DAMGO into the ventrolateral periaqueductal gray. Neuropharmacology 52, 1580-1585, doi:10.1016/j.neuropharm.2007.03.002 (2007). [PubMed: 17445843]

48. Morgan MM, Clayton CC \& Lane DA Behavioral evidence linking opioidsensitive GABAergic neurons in the ventrolateral periaqueductal gray to morphine tolerance. Neuroscience $118,227-$ 232 (2003). [PubMed: 12676152]

49. Morgan MM, Fossum EN, Levine CS \& Ingram SL Antinociceptive tolerance revealed by cumulative intracranial microinjections of morphine into the periaqueductal gray in the rat. 
Pharmacol Biochem Behav 85, 214-219, doi:10.1016/j.pbb.2006.08.003 (2006). [PubMed: 16979226]

50. Tortorici V, Morgan MM \& Vanegas H Tolerance to repeated microinjection of morphine into the periaqueductal gray is associated with changes in the behavior of offand on-cells in the rostral ventromedial medulla of rats. Pain 89, 237-244 (2001). [PubMed: 11166480]

51. Tortorici V, Robbins CS \& Morgan MM Tolerance to the antinociceptive effect of morphine microinjections into the ventral but not lateral-dorsal periaqueductal gray of the rat. Behav Neurosci 113, 833-839 (1999). [PubMed: 10495091]

52. Wong CS, Chang YC, Yeh CC, Huang GS \& Cherng CH Loss of intrathecal morphine analgesia in terminal cancer patients is associated with high levels of excitatory amino acids in the CSF. Can J Anaesth 49, 561-565, doi:10.1007/BF03017381 (2002). [PubMed: 12067866]

53. Tai YH et al. Amitriptyline suppresses neuroinflammation and up-regulates glutamate transporters in morphine-tolerant rats. Pain 124, 77-86, doi:10.1016/j.pain.2006.03.018 (2006). [PubMed: 16697108]

54. Shen $\mathrm{CH}$ et al. Intrathecal etanercept partially restores morphine's antinociception in morphinetolerant rats via attenuation of the glutamatergic transmission. Anesth Analg 113, 184-190, doi: 10.1213/ANE.0b013e318217f7eb (2011). [PubMed: 21490086]

55. Wong CS, Hsu MM, Chou YY, Tao PL \& Tung CS Morphine tolerance increases [3H]MK-801 binding affinity and constitutive neuronal nitric oxide synthase expression in rat spinal cord. $\mathrm{Br} \mathrm{J}$ Anaesth 85, 587-591 (2000). [PubMed: 11064618]

56. Marek P, Ben-Eliyahu S, Gold M \& Liebeskind JC Excitatory amino acid antagonists (kynurenic acid and MK-801) attenuate the development of morphine tolerance in the rat. Brain Res 547, 77 81 (1991). [PubMed: 1860074]

57. Marek P, Ben-Eliyahu S, Vaccarino AL \& Liebeskind JC Delayed application of MK-801 attenuates development of morphine tolerance in rats. Brain Res 558, 163-165 (1991). [PubMed: 1933379]

58. Gonzalez P, Cabello P, Germany A, Norris B \& Contreras E Decrease of tolerance to, and physical dependence on morphine by, glutamate receptor antagonists. Eur J Pharmacol 332, 257-262 (1997). [PubMed: 9300257]

59. Trujillo KA \& Akil H Inhibition of morphine tolerance and dependence by the NMDA receptor antagonist MK-801. Science 251, 85-87 (1991). [PubMed: 1824728]

60. Celerier E, Laulin J, Larcher A, Le Moal M \& Simonnet G Evidence for opiateactivated NMDA processes masking opiate analgesia in rats. Brain Res 847, 18-25 (1999). [PubMed: 10564731]

61. Ben-Eliyahu $\mathrm{S}$ et al. The NMDA receptor antagonist MK-801 prevents long-lasting non-associative morphine tolerance in the rat. Brain Res 575, 304-308 (1992). [PubMed: 1533339]

62. Kest B, McLemore G, Kao B \& Inturrisi CE The competitive alpha-amino-3-hydroxy-5methylisoxazole-4-propionate receptor antagonist LY293558 attenuates and reverses analgesic tolerance to morphine but not to delta or kappa opioids. J Pharmacol Exp Ther 283, 1249-1255 (1997). [PubMed: 9400000]

63. McLemore GL, Kest B \& Inturrisi CE The effects of LY293558, an AMPA receptor antagonist, on acute and chronic morphine dependence. Brain Res 778, 120-126 (1997). [PubMed: 9462883]

64. Bagley EE, Chieng BC, Christie MJ \& Connor M Opioid tolerance in periaqueductal gray neurons isolated from mice chronically treated with morphine. Br J Pharmacol 146, 68-76, doi:10.1038/ sj.bjp.0706315 (2005). [PubMed: 15980868]

65. Morgan MM, Bobeck EN \& Ingram SL Glutamate modulation of antinociception, but not tolerance, produced by morphine microinjection into the periaqueductal gray of the rat. Brain Res 1295, 59-66, doi:10.1016/j.brainres.2009.07.100 (2009). [PubMed: 19664608]

66. Kozela E \& Popik P A complete analysis of NMDA receptor subunits in periaqueductal grey and ventromedial medulla of morphine tolerant mice. Drug Alcohol Depend 86, 290-293, doi:10.1016/ j.drugalcdep.2006.06.018 (2007). [PubMed: 16930867]

67. Tortorici V, Nogueira L, Salas R \& Vanegas H Involvement of local cholecystokinin in the tolerance induced by morphine microinjections into the periaqueductal gray of rats. Pain 102, 9-16 (2003). [PubMed: 12620592] 
68. Boden P \& Woodruff GN Ionic mechanisms underlying cholecystokinin action in rat brain. Ann N Y Acad Sci 713, 129-137 (1994). [PubMed: 7910440]

69. Cox CL, Huguenard JR \& Prince DA Cholecystokinin depolarizes rat thalamic reticular neurons by suppressing a K+ conductance. J Neurophysiol 74, 990-1000 (1995). [PubMed: 7500167]

70. Miller KK, Hoffer A, Svoboda KR \& Lupica CR Cholecystokinin increases GABA release by inhibiting a resting $\mathrm{K}+$ conductance in hippocampal interneurons. J Neurosci 17, 4994-5003 (1997). [PubMed: 9185537]

71. DeLeo JA, Tanga FY \& Tawfik VL Neuroimmune activation and neuroinflammation in chronic pain and opioid tolerance/hyperalgesia. Neuroscientist 10, 40-52, doi:10.1177/1073858403259950 (2004). [PubMed: 14987447]

72. Song P \& Zhao ZQ The involvement of glial cells in the development of morphine tolerance. Neurosci Res 39, 281-286 (2001). [PubMed: 11248367]

73. Hutchinson MR et al. Opioid-induced glial activation: mechanisms of activation and implications for opioid analgesia, dependence, and reward. ScientificWorldJournal 7, 98-111, doi:10.1100/tsw. 2007.230 (2007).

74. Hutchinson MR et al. Proinflammatory cytokines oppose opioid-induced acute and chronic analgesia. Brain Behav Immun 22, 1178-1189, doi:10.1016/j.bbi.2008.05.004 (2008). [PubMed: 18599265]

75. Hutchinson MR et al. Possible involvement of toll-like receptor 4/myeloid differentiation factor-2 activity of opioid inactive isomers causes spinal proinflammation and related behavioral consequences. Neuroscience 167, 880-893, doi:10.1016/j.neuroscience.2010.02.011 (2010). [PubMed: 20178837]

76. Hutchinson MR et al. Minocycline suppresses morphine-induced respiratory depression, suppresses morphine-induced reward, and enhances systemic morphine induced analgesia. Brain Behav Immun 22, 1248-1256, doi:10.1016/j.bbi.2008.07.008 (2008). [PubMed: 18706994]

77. Hutchinson MR et al. Non-stereoselective reversal of neuropathic pain by naloxone and naltrexone: involvement of toll-like receptor 4 (TLR4). Eur J Neurosci 28, 20-29, doi:10.1111/j. 1460-9568.2008.06321.x (2008). [PubMed: 18662331]

78. Hutchinson MR et al. Evidence that opioids may have toll-like receptor 4 and MD-2 effects. Brain Behav Immun 24, 83-95, doi:10.1016/j.bbi.2009.08.004 (2010). [PubMed: 19679181]

79. Lewis SS et al. Evidence that intrathecal morphine-3-glucuronide may cause pain enhancement via toll-like receptor 4/MD-2 and interleukin-1beta. Neuroscience 165, 569-583, doi:10.1016/ j.neuroscience.2009.10.011 (2010). [PubMed: 19833175]

80. Lewis SS et al. Glucuronic acid and the ethanol metabolite ethyl-glucuronide cause toll-like receptor 4 activation and enhanced pain. Brain Behav Immun, doi:10.1016/j.bbi.2013.01.005 (2013).

81. Wang X et al. Morphine activates neuroinflammation in a manner parallel to endotoxin. Proc Natl Acad Sci U S A 109, 6325-6330, doi:10.1073/pnas.1200130109 (2012). [PubMed: 22474354]

82. Eidson LN \& Murphy AZ Blockade of Toll-like receptor 4 attenuates morphine tolerance and facilitates the pain relieving properties of morphine. J Neurosci 33, 15952-15963, doi:10.1523/ JNEUROSCI.1609-13.2013 (2013). [PubMed: 24089500]

83. Eidson LN \& Murphy AZ Persistent peripheral inflammation attenuates morphineinduced periaqueductal gray glial cell activation and analgesic tolerance in the male rat. J Pain 14, 393 404, doi:10.1016/j.jpain.2012.12.010 (2013). [PubMed: 23395474]

84. Johnston IN et al. A role for proinflammatory cytokines and fractalkine in analgesia, tolerance, and subsequent pain facilitation induced by chronic intrathecal morphine. J Neurosci $24,7353-7365$, doi:10.1523/JNEUROSCI.1850-04.2004 (2004). [PubMed: 15317861]

85. Watkins LR, Hutchinson MR, Johnston IN \& Maier SF Glia: novel counterregulators of opioid analgesia. Trends Neurosci 28, 661-669, doi:10.1016/j.tins.2005.10.001 (2005). [PubMed: 16246435]

86. Raghavendra V, Rutkowski MD \& DeLeo JA The role of spinal neuroimmune activation in morphine tolerance/hyperalgesia in neuropathic and sham-operated rats. J Neurosci 22, 9980-9989 (2002). [PubMed: 12427855] 
87. Raghavendra V, Tanga FY \& DeLeo JA Attenuation of morphine tolerance, withdrawal-induced hyperalgesia, and associated spinal inflammatory immune responses by propentofylline in rats. Neuropsychopharmacology 29, 327-334, doi:10.1038/sj.npp.1300315 (2004). [PubMed: 14532913]

88. Watkins LR et al. Norman Cousins Lecture. Glia as the "bad guys": implications for improving clinical pain control and the clinical utility of opioids. Brain Behav Immun 21, 131-146, doi: 10.1016/j.bbi.2006.10.011 (2007). [PubMed: 17175134]

89. Watkins LR, Hutchinson MR, Rice KC \& Maier SF The "toll" of opioidinduced glial activation: improving the clinical efficacy of opioids by targeting glia. Trends Pharmacol Sci 30, 581-591, doi:10.1016/j.tips.2009.08.002 (2009). [PubMed: 19762094]

90. Watkins LR, Milligan ED \& Maier SF Spinal cord glia: new players in pain. Pain 93, 201-205 (2001). [PubMed: 11514078]

91. Mika J, Wawrzczak-Bargiela A, Osikowicz M, Makuch W \& Przewlocka B Attenuation of morphine tolerance by minocycline and pentoxifylline in naive and neuropathic mice. Brain Behav Immun 23, 75-84, doi:10.1016/j.bbi.2008.07.005 (2009). [PubMed: 18684397]

92. Mika J Modulation of microglia can attenuate neuropathic pain symptoms and enhance morphine effectiveness. Pharmacol Rep 60, 297-307 (2008). [PubMed: 18622054]

93. Raghavendra V, Tanga F, Rutkowski MD \& DeLeo JA Anti-hyperalgesic and morphine-sparing actions of propentofylline following peripheral nerve injury in rats: mechanistic implications of spinal glia and proinflammatory cytokines. Pain 104, 655-664 (2003). [PubMed: 12927638]

94. Sweitzer SM, Schubert P \& DeLeo JA Propentofylline, a glial modulating agent, exhibits antiallodynic properties in a rat model of neuropathic pain. J Pharmacol Exp Ther 297, 1210-1217 (2001). [PubMed: 11356948]

95. Tawfik VL, Nutile-McMenemy N, Lacroix-Fralish ML \& Deleo JA Efficacy of propentofylline, a glial modulating agent, on existing mechanical allodynia following peripheral nerve injury. Brain Behav Immun 21, 238-246, doi:10.1016/j.bbi.2006.07.001 (2007). [PubMed: 16949251]

96. Cui Y et al. A novel role of minocycline: attenuating morphine antinociceptive tolerance by inhibition of p38 MAPK in the activated spinal microglia. Brain Behav Immun 22, 114-123, doi: 10.1016/j.bbi.2007.07.014 (2008). [PubMed: 17919885]

97. Hameed H, Hameed M \& Christo PJ The effect of morphine on glial cells as a potential therapeutic target for pharmacological development of analgesic drugs. Curr Pain Headache Rep 14, 96-104, doi:10.1007/s11916-010-0093-y (2010). [PubMed: 20425198]

98. Juni A, Klein G, Pintar JE \& Kest B Nociception increases during opioid infusion in opioid receptor triple knock-out mice. Neuroscience 147, 439-444, doi:10.1016/j.neuroscience. 2007.04.030 (2007). [PubMed: 17544222]

99. Lehnardt $\mathrm{S}$ et al. Activation of innate immunity in the CNS triggers neurodegeneration through a Toll-like receptor 4-dependent pathway. Proc Natl Acad Sci U S A 100, 8514-8519, doi:10.1073/ pnas.1432609100 (2003). [PubMed: 12824464]

100. Jou I et al. Gangliosides trigger inflammatory responses via TLR4 in brain glia. Am J Pathol 168, 1619-1630, doi:10.2353/ajpath.2006.050924 (2006). [PubMed: 16651628]

101. Jin $\mathrm{H}$ et al. Lipoxin A4 analog attenuates morphine antinociceptive tolerance, withdrawal-induced hyperalgesia, and glial reaction and cytokine expression in the spinal cord of rat. Neuroscience 208, 1-10, doi:10.1016/j.neuroscience.2012.02.009 (2012). [PubMed: 22366510]

102. Shen $\mathrm{CH}$ et al. Etanercept restores the antinociceptive effect of morphine and suppresses spinal neuroinflammation in morphine-tolerant rats. Anesth Analg 112, 454-459, doi:10.1213/ANE. 0b013e3182025b15 (2011). [PubMed: 21081778]

103. Zeng X, Lin MY, Wang D, Zhang Y \& Hong Y Involvement of adrenomedullin in spinal glial activation following chronic administration of morphine in rats. Eur J Pain, doi:10.1002/j. 1532-2149.2014.493.x (2014).

104. Wang Z, Ma W, Chabot JG \& Quirion R Cell-type specific activation of p38 and ERK mediates calcitonin gene-related peptide involvement in tolerance to morphineinduced analgesia. FASEB journal : official publication of the Federation of American Societies for Experimental Biology 23, 2576-2586, doi:10.1096/fj.08-128348 (2009). [PubMed: 19299480] 
105. Lin SL et al. Ultra-low dose naloxone upregulates interleukin-10 expression and suppresses neuroinflammation in morphine-tolerant rat spinal cords. Behav Brain Res 207, 30-36, doi: 10.1016/j.bbr.2009.09.034 (2010). [PubMed: 19799935]

106. Sun J, Liu S, Mata M, Fink DJ \& Hao S Transgene-mediated expression of tumor necrosis factor soluble receptor attenuates morphine tolerance in rats. Gene Ther 19, 101-108, doi:10.1038/gt. 2011.76 (2012). [PubMed: 21614028]

107. Hutchinson MR et al. Reduction of opioid withdrawal and potentiation of acute opioid analgesia by systemic AV411 (ibudilast). Brain Behav Immun 23, 240-250, doi:10.1016/j.bbi.2008.09.012 (2009). [PubMed: 18938237]

108. Chang YW \& Waxman SG Minocycline attenuates mechanical allodynia and central sensitization following peripheral second-degree burn injury. J Pain 11, 1146-1154, doi:10.1016/j.jpain. 2010.02.010 (2010). [PubMed: 20418178]

109. Tawfik VL, Nutile-McMenemy N, LaCroix-Fralish ML \& DeLeo JA Reprint of "efficacy of propentofylline, a glial modulating agent, on existing mechanical allodynia following peripheral nerve injury" [Brain Behav. Immun. 21 (2007) 238-246]. Brain Behav Immun 21, 677-685, doi: 10.1016/S0889-1591(07)00095-5 (2007). [PubMed: 17544848]

110. Gul H, Yildiz O, Dogrul A, Yesilyurt O \& Isimer A The interaction between IL-1beta and morphine: possible mechanism of the deficiency of morphine-induced analgesia in diabetic mice. Pain 89, 39-45 (2000). [PubMed: 11113291]

111. Hutchinson MR et al. Exploring the neuroimmunopharmacology of opioids: an integrative review of mechanisms of central immune signaling and their implications for opioid analgesia. Pharmacol Rev 63, 772-810, doi:10.1124/pr.110.004135 (2011). [PubMed: 21752874]

112. Sawaya BE, Deshmane SL, Mukerjee R, Fan S \& Khalili K TNF alpha production in morphinetreated human neural cells is NF-kappaB-dependent. J Neuroimmune Pharmacol 4, 140-149, doi: 10.1007/s11481-008-9137-z (2009). [PubMed: 19023660]

113. Smith FL et al. Prolonged reversal of morphine tolerance with no reversal of dependence by protein kinase C inhibitors. Brain Res 958, 28-35 (2002). [PubMed: 12468027]

114. Sim-Selley LJ et al. Region-dependent attenuation of mu opioid receptor-mediated Gprotein activation in mouse CNS as a function of morphine tolerance. Br J Pharmacol 151, 1324-1333, doi:10.1038/sj.bjp.0707328 (2007). [PubMed: 17572699]

115. Arttamangkul S et al. Differential activation and trafficking of micro-opioid receptors in brain slices. Mol Pharmacol 74, 972-979, doi:10.1124/mol.108.048512 (2008). [PubMed: 18612077]

116. McPherson J et al. mu-opioid receptors: correlation of agonist efficacy for signaling with ability to activate internalization. Mol Pharmacol 78, 756-766, doi:10.1124/mol.110.066613 (2010). [PubMed: 20647394]

117. Eidson LN, Inoue K, Young LJ, Tansey MG \& Murphy AZ Toll-like Receptor 4 Mediates Morphine-Induced Neuroinflammation and Tolerance via Soluble Tumor Necrosis Factor Signaling. Neuropsychopharmacology 42, 661-670, doi:10.1038/npp.2016.131 (2017). [PubMed: 27461080]

118. Colburn RW, Rickman AJ \& DeLeo JA The effect of site and type of nerve injury on spinal glial activation and neuropathic pain behavior. Exp Neurol 157, 289-304, doi:10.1006/exnr.1999.7065 (1999). [PubMed: 10364441]

119. Ogoshi $\mathrm{F}$ et al. Tumor necrosis-factor-alpha (TNF-alpha) induces rapid insertion of Ca2+permeable alpha-amino-3-hydroxyl-5-methyl-4-isoxazole-propionate (AMPA)/kainate (Ca-A/K) channels in a subset of hippocampal pyramidal neurons. Exp Neurol 193, 384-393, doi:10.1016/ j.expneurol.2004.12.026 (2005). [PubMed: 15869941]

120. Stellwagen D, Beattie EC, Seo JY \& Malenka RC Differential regulation of AMPA receptor and GABA receptor trafficking by tumor necrosis factor-alpha. J Neurosci 25, 3219-3228, doi: 10.1523/JNEUROSCI.4486-04.2005 (2005). [PubMed: 15788779]

121. Viviani B et al. Interleukin-1beta enhances NMDA receptor-mediated intracellular calcium increase through activation of the Src family of kinases. J Neurosci 23, 8692-8700 (2003). [PubMed: 14507968] 
122. Horvath RJ \& DeLeo JA Morphine enhances microglial migration through modulation of P2X4 receptor signaling. J Neurosci 29, 998-1005, doi:10.1523/JNEUROSCI.4595-08.2009 (2009). [PubMed: 19176808]

123. Collett BJ Opioid tolerance: the clinical perspective. Br J Anaesth 81, 58-68 (1998). [PubMed: 9771273]

124. Dworkin RH et al. Core outcome measures for chronic pain clinical trials: IMMPACT recommendations. Pain 113, 9-19, doi:10.1016/j.pain.2004.09.012 (2005). [PubMed: 15621359]

125. Galer BS, Lee D, Ma T, Nagle B \& Schlagheck TG MorphiDex (morphine sulfate/ dextromethorphan hydrobromide combination) in the treatment of chronic pain: three multicenter, randomized, double-blind, controlled clinical trials fail to demonstrate enhanced opioid analgesia or reduction in tolerance. Pain 115, 284-295, doi:10.1016/j.pain.2005.03.004 (2005). [PubMed: 15911155]

126. Kalso E, Edwards JE, Moore RA \& McQuay HJ Opioids in chronic non-cancer pain: systematic review of efficacy and safety. Pain 112, 372-380, doi:10.1016/j.pain.2004.09.019 (2004). [PubMed: 15561393]

127. Mehalick ML, Ingram SL, Aicher SA \& Morgan MM Chronic inflammatory pain prevents tolerance to the antinociceptive effect of morphine microinjected into the ventrolateral periaqueductal gray of the rat. J Pain 14, 1601-1610, doi:10.1016/j.jpain.2013.08.003 (2013). [PubMed: 24161274]

128. Tonsfeldt KJ et al. Sex Differences in GABAA Signaling in the Periaqueductal Gray Induced by Persistent Inflammation. J Neurosci 36, 1669-1681, doi:10.1523/JNEUROSCI.1928-15.2016 (2016). [PubMed: 26843648]

129. Wei F, Guo W, Zou S, Ren K \& Dubner R Supraspinal glial-neuronal interactions contribute to descending pain facilitation. J Neurosci 28, 10482-10495, doi:10.1523/JNEUROSCI. 3593-08.2008 (2008). [PubMed: 18923025]

130. Chen FL et al. Activation of astrocytes in the anterior cingulate cortex contributes to the affective component of pain in an inflammatory pain model. Brain Res Bull 87, 60-66, doi:10.1016/ j.brainresbull.2011.09.022 (2012). [PubMed: 22004615]

131. Mi WL et al. Involvement of spinal neurotrophin-3 in electroacupuncture analgesia and inhibition of spinal glial activation in rat model of monoarthritis. J Pain 12, 974-984, doi:10.1016/j.jpain. 2011.03.002 (2011). [PubMed: 21680256]

132. Raghavendra V, Tanga FY \& DeLeo JA Complete Freunds adjuvant-induced peripheral inflammation evokes glial activation and proinflammatory cytokine expression in the CNS. Eur $\mathbf{J}$ Neurosci 20, 467-473, doi:10.1111/j.1460-9568.2004.03514.x (2004). [PubMed: 15233755]

133. Sun $\mathrm{S}$ et al. New evidence for the involvement of spinal fractalkine receptor in pain facilitation and spinal glial activation in rat model of monoarthritis. Pain 129, 64-75, doi:10.1016/j.pain. 2006.09.035 (2007). [PubMed: 17123734]

134. Tanga FY, Raghavendra V, Nutile-McMenemy N, Marks A \& Deleo JA Role of astrocytic S100beta in behavioral hypersensitivity in rodent models of neuropathic pain. Neuroscience 140 , 1003-1010, doi:10.1016/j.neuroscience.2006.02.070 (2006). [PubMed: 16600520]

135. Gazda LS et al. Sciatic inflammatory neuritis (SIN): behavioral allodynia is paralleled by perisciatic proinflammatory cytokine and superoxide production. J Peripher Nerv Syst 6, 111-129 (2001). [PubMed: 11817330]

136. Lin $\mathrm{T}$ et al. Dissociation of spinal microglia morphological activation and peripheral inflammation in inflammatory pain models. J Neuroimmunol 192, 40-48, doi:10.1016/ j.jneuroim.2007.09.003 (2007). [PubMed: 17919739]

137. Honore $\mathrm{P}$ et al. Murine models of inflammatory, neuropathic and cancer pain each generates a unique set of neurochemical changes in the spinal cord and sensory neurons. Neuroscience 98 , 585-598 (2000). [PubMed: 10869852]

138. Chang YW, Tan A, Saab C \& Waxman S Unilateral focal burn injury is followed by long-lasting bilateral allodynia and neuronal hyperexcitability in spinal cord dorsal horn. J Pain 11, 119-130, doi:10.1016/j.jpain.2009.06.009 (2010). [PubMed: 19744891] 
139. Shields $\mathrm{SD}$ et al. Sodium channel $\mathrm{Na}(\mathrm{v}) 1.7$ is essential for lowering heat pain threshold after burn injury. J Neurosci 32, 10819-10832, doi:10.1523/JNEUROSCI.0304-12.2012 (2012). [PubMed: 22875917]

140. Sorkin L, Svensson CI, Jones-Cordero TL, Hefferan MP \& Campana WM Spinal p38 mitogenactivated protein kinase mediates allodynia induced by first-degree burn in the rat. J Neurosci Res 87, 948-955, doi:10.1002/jnr.21905 (2009). [PubMed: 18855936]

141. Ortiz-Ferron $\mathrm{G}$ et al. The mitogen-activated protein kinase pathway can inhibit TRAILinduced apoptosis by prohibiting association of truncated Bid with mitochondria. Cell Death Differ 13, 1857-1865, doi:10.1038/sj.cdd.4401875 (2006). [PubMed: 16485030]

142. Wyss-Coray T \& Mucke L Inflammation in neurodegenerative disease--a double-edged sword. Neuron 35, 419-432 (2002). [PubMed: 12165466]

143. Cao L, Tanga FY \& Deleo JA The contributing role of CD14 in toll-like receptor 4 dependent neuropathic pain. Neuroscience 158, 896-903, doi:10.1016/j.neuroscience.2008.10.004 (2009). [PubMed: 18976692]

144. Tanga FY, Nutile-McMenemy N \& DeLeo JA The CNS role of Toll-like receptor 4 in innate neuroimmunity and painful neuropathy. Proc Natl Acad Sci U S A 102, 5856-5861, doi:10.1073/ pnas.0501634102 (2005). [PubMed: 15809417]

145. Watkins LR, Milligan ED \& Maier SF Glial activation: a driving force for pathological pain. Trends Neurosci 24, 450-455 (2001). [PubMed: 11476884]

146. Costantini TW et al. Targeting alpha-7 nicotinic acetylcholine receptor in the enteric nervous system: a cholinergic agonist prevents gut barrier failure after severe burn injury. Am J Pathol 181, 478-486, doi:10.1016/j.ajpath.2012.04.005 (2012). [PubMed: 22688057]

147. Schwacha MG, Thobe BM, Daniel T \& Hubbard WJ Impact of thermal injury on wound infiltration and the dermal inflammatory response. J Surg Res 158, 112-120, doi:10.1016/j.jss. 2008.07.034 (2010). [PubMed: 19394637]

148. Bian JT \& Bhargava HN Effects of morphine-3-glucuronide on the antinociceptive activity of peptide and nonpeptide opioid receptor agonists in mice. Peptides 17, 1415-1419 (1996). [PubMed: 8971939]

149. Schwarz JM \& Bilbo SD Adolescent morphine exposure affects long-term microglial function and later-life relapse liability in a model of addiction. J Neurosci 33, 961-971, doi:10.1523/ JNEUROSCI.2516-12.2013 (2013). [PubMed: 23325235]

150. Coull JA et al. BDNF from microglia causes the shift in neuronal anion gradient underlying neuropathic pain. Nature 438, 1017-1021, doi:10.1038/nature04223 (2005). [PubMed: 16355225]

151. Caldeira MV et al. Brain-derived neurotrophic factor regulates the expression and synaptic delivery of alpha-amino-3-hydroxy-5-methyl-4-isoxazole propionic acid receptor subunits in hippocampal neurons. J Biol Chem 282, 12619-12628, doi:10.1074/jbc.M700607200 (2007). [PubMed: 17337442]

152. Caldeira MV et al. BDNF regulates the expression and traffic of NMDA receptors in cultured hippocampal neurons. Mol Cell Neurosci 35, 208-219, doi:10.1016/j.mcn.2007.02.019 (2007). [PubMed: 17428676]

153. Matsushita Y, Omotuyi IO, Mukae T \& Ueda H Microglia activation precedes the anti-opioid BDNF and NMDA receptor mechanisms underlying morphine analgesic tolerance. Curr Pharm Des 19, 7355-7361 (2013). [PubMed: 23448475]

154. Chapman GA et al. Fractalkine cleavage from neuronal membranes represents an acute event in the inflammatory response to excitotoxic brain damage. J Neurosci 20, RC87 (2000). [PubMed: 10899174]

155. Chapman GA et al. The role of fractalkine in the recruitment of monocytes to the endothelium. Eur J Pharmacol 392, 189-195 (2000). [PubMed: 10762673]

156. Jones BA, Beamer M \& Ahmed S Fractalkine/CX3CL1: a potential new target for inflammatory diseases. Mol Interv 10, 263-270, doi:10.1124/mi.10.5.3 (2010). [PubMed: 21045240]

157. Mitchell JM, Basbaum AI \& Fields HL A locus and mechanism of action for associative morphine tolerance. Nat Neurosci 3, 47-53, doi:10.1038/71120 (2000). [PubMed: 10607394] 
158. Skinner K, Basbaum AI \& Fields HL Cholecystokinin and enkephalin in brain stem pain modulating circuits. Neuroreport 8, 2995-2998 (1997). [PubMed: 9331904]

159. Shen $\mathrm{N}$ et al. A novel role of spinal astrocytic connexin 43: mediating morphine antinociceptive tolerance by activation of NMDA receptors and inhibition of glutamate transporter-1 in rats. CNS Neurosci Ther 20, 728-736, doi:10.1111/cns.12244 (2014). [PubMed: 24629168]

160. Steed PM et al. Inactivation of TNF signaling by rationally designed dominantnegative TNF variants. Science 301, 1895-1898, doi:10.1126/science.1081297 (2003). [PubMed: 14512626]

161. Zalevsky J et al. Dominant-negative inhibitors of soluble TNF attenuate experimental arthritis without suppressing innate immunity to infection. J Immunol 179, 1872-1883 (2007). [PubMed: 17641054]

162. Gutstein HB, Mansour A, Watson SJ, Akil H \& Fields HL Mu and kappa opioid receptors in periaqueductal gray and rostral ventromedial medulla. Neuroreport 9, 1777-1781 (1998). [PubMed: 9665599]

163. Mansour A, Khachaturian H, Lewis ME, Akil H \& Watson SJ Autoradiographic differentiation of $\mathrm{mu}$, delta, and kappa opioid receptors in the rat forebrain and midbrain. J Neurosci 7, 2445-2464 (1987). [PubMed: 3039080]

164. Mansour A, Lewis ME, Khachaturian H, Akil H \& Watson SJ Pharmacological and anatomical evidence of selective mu, delta, and kappa opioid receptor binding in rat brain. Brain Res 399, 69-79 (1986). [PubMed: 3026574]

165. Kalyuzhny AE, Arvidsson U, Wu W \& Wessendorf MW mu-Opioid and deltaopioid receptors are expressed in brainstem antinociceptive circuits: studies using immunocytochemistry and retrograde tract-tracing. J Neurosci 16, 6490-6503 (1996). [PubMed: 8815927]

166. Commons KG, Aicher SA, Kow LM \& Pfaff DW Presynaptic and postsynaptic relations of muopioid receptors to gamma-aminobutyric acid-immunoreactive and medullary-projecting periaqueductal gray neurons. J Comp Neurol 419, 532-542 (2000). [PubMed: 10742719]

167. Commons KG, van Bockstaele EJ \& Pfaff DW Frequent colocalization of mu opioid and NMDAtype glutamate receptors at postsynaptic sites in periaqueductal gray neurons. J Comp Neurol 408, 549-559 (1999). [PubMed: 10340504]

168. Jacquet YF \& Lajtha A The periaqueductal gray: site of morphine analgesia and tolerance as shown by 2-way cross tolerance between systemic and intracerebral injections. Brain Res 103, 501-513 (1976). [PubMed: 1252940]

169. Fang FG, Haws CM, Drasner K, Williamson A \& Fields HL Opioid peptides (DAGO-enkephalin, dynorphin A(1-13), BAM 22P) microinjected into the rat brainstem: comparison of their antinociceptive effect and their effect on neuronal firing in the rostral ventromedial medulla. Brain Res 501, 116-128 (1989). [PubMed: 2572306]

170. Rossi GC, Pasternak GW \& Bodnar RJ Mu and delta opioid synergy between the periaqueductal gray and the rostro-ventral medulla. Brain Res 665, 85-93 (1994). [PubMed: 7882023]

171. Morgan MM, Whitney PK \& Gold MS Immobility and flight associated with antinociception produced by activation of the ventral and lateral/dorsal regions of the rat periaqueductal gray. Brain Res 804, 159-166 (1998). [PubMed: 9729359]

172. Fairbanks CA \& Wilcox GL Spinal plasticity of acute opioid tolerance. J Biomed Sci 7, 200-212, doi:25449 (2000). [PubMed: 10810238]

173. Bobeck EN, McNeal AL \& Morgan MM Drug dependent sex-differences in periaqueducatal gray mediated antinociception in the rat. Pain 147, 210-216, doi:10.1016/j.pain.2009.09.008 (2009). [PubMed: 19796879]

174. Pert A \& Yaksh T Sites of morphine induced analgesia in the primate brain: relation to pain pathways. Brain Res 80, 135-140 (1974). [PubMed: 4424093]

175. Ossipov MH, Goldstein FJ \& Malseed RT Feline analgesia following central administration of opioids. Neuropharmacology 23, 925-929 (1984). [PubMed: 6483117]

176. Camarata PJ \& Yaksh TL Characterization of the spinal adrenergic receptors mediating the spinal effects produced by the microinjection of morphine into the periaqueductal gray. Brain Res 336, 133-142 (1985). [PubMed: 2988700] 
177. Jensen TS \& Yaksh TL Comparison of the antinociceptive action of mu and delta opioid receptor ligands in the periaqueductal gray matter, medial and paramedial ventral medulla in the rat as studied by the microinjection technique. Brain Res 372, 301-312 (1986). [PubMed: 2871901]

178. Jensen TS \& Yaksh TL Comparison of antinociceptive action of morphine in the periaqueductal gray, medial and paramedial medulla in rat. Brain Res 363, 99-113 (1986). [PubMed: 3004644]

179. Yaksh TL \& Rudy TA Narcotic analgestics: CNS sites and mechanisms of action as revealed by intracerebral injection techniques. Pain 4, 299-359 (1978). [PubMed: 25403]

180. Satoh $\mathrm{M}$ et al. Comparison of analgesic potencies of mu, delta and kappa agonists locally applied to various CNS regions relevant to analgesia in rats. Life Sci 33 Suppl 1, 689-692 (1983). [PubMed: 6141508]

181. Bodnar RJ, Romero MT \& Kramer E Organismic variables and pain inhibition: roles of gender and aging. Brain Res Bull 21, 947-953 (1988). [PubMed: 3066444]

182. Bodnar RJ, Williams CL, Lee SJ \& Pasternak GW Role of mu 1-opiate receptors in supraspinal opiate analgesia: a microinjection study. Brain Res 447, 25-34 (1988). [PubMed: 2838129]

183. Cheng ZF, Fields HL \& Heinricher MM Morphine microinjected into the periaqueductal gray has differential effects on 3 classes of medullary neurons. Brain Res 375, 57-65 (1986). [PubMed: 3719359]

184. Lewis VA \& Gebhart GF Morphine-induced and stimulation-produced analgesias at coincident periaqueductal central gray loci: evaluation of analgesic congruence, tolerance, and crosstolerance. Exp Neurol 57, 934-955 (1977). [PubMed: 923683]

185. Lewis VA \& Gebhart GF Evaluation of the periaqueductal central gray (PAG) as a morphinespecific locus of action and examination of morphine-induced and stimulationproduced analgesia at coincident PAG loci. Brain Res 124, 283-303 (1977). [PubMed: 191150]

186. Loyd DR, Wang X \& Murphy AZ Sex differences in micro-opioid receptor expression in the rat midbrain periaqueductal gray are essential for eliciting sex differences in morphine analgesia. $\mathrm{J}$ Neurosci 28, 14007-14017, doi:10.1523/JNEUROSCI.4123-08.2008 (2008). [PubMed: 19109484]

187. Seror R et al. Pattern of demyelination occurring during anti-TNF-alpha therapy: a French national survey. Rheumatology (Oxford) 52, 868-874, doi:10.1093/rheumatology/kes375 (2013). [PubMed: 23287362]

188. Marchetti L, Klein M, Schlett K, Pfizenmaier K \& Eisel UL Tumor necrosis factor (TNF)mediated neuroprotection against glutamate-induced excitotoxicity is enhanced by N-methyl-Daspartate receptor activation. Essential role of a TNF receptor 2-mediated phosphatidylinositol 3kinase-dependent NF-kappa B pathway. J Biol Chem 279, 32869-32881, doi:10.1074/ jbc.M311766200 (2004). [PubMed: 15155767] 


\section{Highlights}

- $\quad$ Our recent studies establish a role for PAG microglia, and in particular TLR4 signaling, in the development of morphine tolerance.

- We present data indicating that soluble TNF (solTNF) is the important TNF isoform mediating opioid tolerance and alterations in glutamate homeostasis and that exclusive sequestration of solTNF in the vIPAG prevents opioidinduced neuroinflammation and the ensuing changes in glutamate homeostasis and development of morphine tolerance.

- $\quad$ Our studies identify the anti-TNF biologic XPro®1595 as a potential tool to accompany opioid therapy in the clinic. XPro®1595 may be preferable over current FDA approved anti-TNF biologies (Etanercept, Infliximab, Adalimumab). 

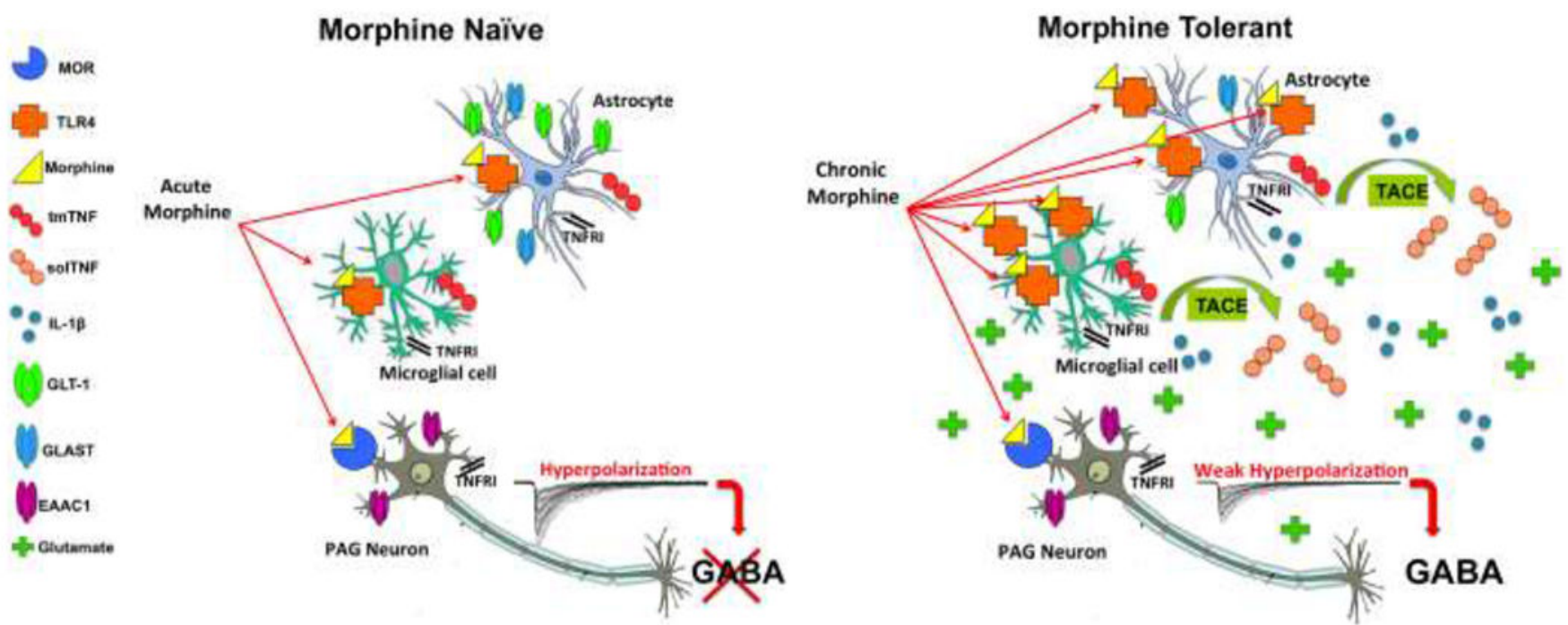

Figure 1. A schematic diagram illustrating major conclusions and hypotheses.

Chronic morphine binds to vIPAG TLR4 and leads to solTNF signaling that increases proinflammatory gene expression (TLR4, IL-1 $\beta$ ) and decreases astrocytic glutamate transporter mRNA (GLT-1 and GLAST) in the vIPAG. These changes effectively increase the availability of glutamate in the synapse, thereby decreasing the ability of morphine to hyperpolarize GABAergic neurons. These changes associated with morphine tolerance prevent morphine from initiating signaling through the descending analgesic circuit. 